\title{
ChemComm
}

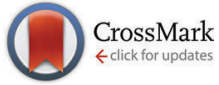

Cite this: Chem. Commun., 2016, 52,8467

Received 15th April 2016,

Accepted 2nd June 2016

DOI: $10.1039 / c 6 c c 03185 d$

www.rsc.org/chemcomm

\section{Solvent responsive catalyst improves NMR sensitivity via efficient magnetisation transfer $\dagger$}

\author{
Amy J. Ruddlesden and Simon B. Duckett*
}

\begin{abstract}
A bidentate iridium carbene complex, $\operatorname{Ir}\left(\kappa \mathrm{C}, \mathrm{O}-\mathrm{L}_{1}\right)(\mathrm{COD})$, has been synthesised which contains a strongly electron donating carbene ligand that is functionalised by a cis-spanning phenolate group. This complex acts as a precursor to effective magnetisation transfer catalysts which form after reaction with $\mathrm{H}_{2}$ and a suitable two electron donor. In solvents such as benzene, containing pyridine, they are exemplified by neutral, chiral $\operatorname{Ir}(\mathrm{H})_{2}\left(\kappa \mathrm{C}, \mathrm{O}-\mathrm{L}_{1}\right)(\mathrm{py})_{2}$ with inequivalent hydride ligands and Ir-O bond retention, whilst in methanol, Ir-O bond cleavage leads to zwitterionic $\left[\operatorname{Ir}(\mathrm{H})_{2}\left(\kappa \mathrm{C}, \mathrm{O}^{-}-\mathrm{L}_{1}\right)(\mathrm{py})_{3}\right]^{+}$, with chemically equivalent hydride ligands. The active catalyst's form is therefore solvent dependent. Both these complexes break the magnetic symmetry of the hydride ligands and are active in the catalytic transfer of polarisation from parahydrogen to a loosely bound ligand. Test results on pyridine, nicotinaldehyde and nicotine reveal up to $\approx 1.2 \%$ single spin proton polarisation levels in their ${ }^{1} \mathrm{H}$ NMR signals which compare to the normal $0.003 \%$ level at 9.4 Tesla. These results exemplify how rational catalyst design yields a solvent dependent catalyst with good SABRE activity.
\end{abstract}

The use of hyperpolarisation methods to overcome the inherent insensitivity of NMR spectroscopy reflects an area of research where Parahydrogen Induced Polarisation (PHIP) features heavily. ${ }^{1}$ The incorporation of parahydrogen $\left(p-\mathrm{H}_{2}\right)$, a nuclear singlet, into a molecule was first shown to produce an enhanced NMR signal in 1987. ${ }^{2}$ The increase in signal intensity for resonances arising from, or coupled to, $p-\mathrm{H}_{2}$ derived protons, has since been the subject of intense investigation. Recently a $p-\mathrm{H}_{2}$ technique that does not chemically change a molecule, called Signal Amplification By Reversible Exchange (SABRE), has been developed. ${ }^{3}$ Polarisation is transferred through $J$-coupling between the $p-\mathrm{H}_{2}$ derived hydride

Centre for Hyperpolarisation in Magnetic Resonance (CHyM), York Science Park, University of York, Heslington, York, YO10 5NY, UK.

E-mail: simon.duckett@york.ac.uk; Tel: +44 (0)1904 322564

$\dagger$ Electronic supplementary information (ESI) available: Experimental details; synthesis and characterisation of compounds, SABRE experiments, kinetic data, activation parameters, UV-vis data. The underlying research data for this paper is available in accordance with EPSRC open data policy from DOI: 10.15124/ cdaf969f-ba47-401e-876b-512c0cece55c. See DOI: 10.1039/c6cc03185d ligands and the substrate ligands. ${ }^{3}$ Exchange with free substrate and fresh $p-\mathrm{H}_{2}$ enables the build-up of polarisation in the substrate pool through multiple visits to the catalyst. The most commonly used catalysts are cationic species which contain either phosphine ${ }^{4,5}$ or N-heterocyclic carbene (NHC) ligands. ${ }^{6,7}$

In fact, one of the most effective magnetisation transfer catalysts is $\operatorname{Ir}(\mathrm{COD})(\mathrm{IMes}) \mathrm{Cl}^{7}$ [where IMes $=1,3$-bis(2,4,6trimethylphenyl)imidazole-2-ylidene, $\mathrm{COD}=$ cyclooctadiene] which forms the charged complex, $\left[\operatorname{Ir}(\mathrm{H})_{2}(\mathrm{IMes})(\text { substrate })_{3}\right] \mathrm{Cl}$ once activated with $\mathrm{H}_{2}$ and a substrate. This SABRE catalyst contains chemically equivalent but magnetically inequivalent hydride ligands and polarisation transfer has proven particularly efficient in polar protic solvents such as methanol. Furthermore, using this catalyst a wide range of substrates including nicotinamide, ${ }^{8-10}$ isoniazid $^{11}$ and pyrazole ${ }^{12}$ have been shown to become hyperpolarised. This type of approach has been exemplified for ${ }^{1} \mathrm{H},{ }^{13} \mathrm{C},{ }^{31} \mathrm{P},{ }^{19} \mathrm{~F}$ and ${ }^{15} \mathrm{~N}$ nuclei. ${ }^{5,13-15}$ However, due to the charged nature of such a species, it has proven less efficient in the range of low polarity solvents commonly used in NMR analysis.

It has also been shown that species with chemically inequivalent hydride ligands can act as SABRE catalysts. One reported example of this class of catalyst is given by $\left[\mathrm{Ir}(\mathrm{H})_{2}\left(\mathrm{CH}_{3} \mathrm{CN}\right)(\mathrm{IMes})-\right.$ $\left(\mathrm{PCy}_{3}\right)$ (pyridine)]Cl. ${ }^{16}$ Recently, a system that exhibits a wider solvent tolerance has been developed. It contains a bidentate ligand which binds through carbene and phenolate centres, resulting in a neutral catalyst in all solvents tested. While it was found to exhibit greater activity in non-polar solvents such as benzene, ${ }^{17}$ it was not efficient in methanol due to much slower ligand exchange.

In this study, the related neutral iridium complex, $\operatorname{Ir}\left(\kappa \mathrm{C}, \mathrm{O}-\mathrm{L}_{1}\right)-$ (COD), 1, [where $\mathrm{L}_{1}=3$-(2-methylene-phenolate)-1-(2,4,6-trimethylphenyl)imidazolylidene], has been synthesised starting from salicylaldehyde. It contains a cis-spanning phenolate-substituted bidentate NHC (see Scheme 1). Benzyl protection of the phenol ${ }^{18}$ allowed conversion of the aldehyde to the bromide ${ }^{19}$ via the alcohol. ${ }^{20}$ Addition of 1-(2,4,6-trimethylphenyl)- $1 H$-imidazole then formed the imidazolium bromide salt. ${ }^{21}$ Deprotection followed by silver carbene formation and subsequent transmetallation ${ }^{22}$ 

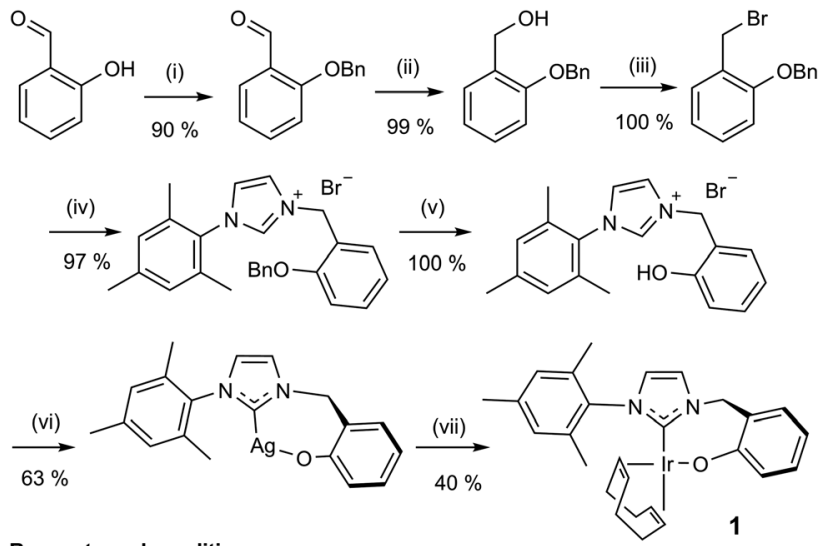

Reagents and conditions:

(i) Acetone, $\mathrm{K}_{2} \mathrm{CO}_{3}, \mathrm{BnBr}$, reflux, $2 \mathrm{~h}$; (ii) $\mathrm{NaBH}_{4}, \mathrm{MeOH}, 0^{\circ} \mathrm{C}$ then r.t., $30 \mathrm{~min}$;

(iii) $\mathrm{PBr}_{3}, \mathrm{DCM}$, r.t., $2 \mathrm{~h}$; (iv) 1-(2,4,6-trimethylphenyl)-1H-imidazole, toluene, reflux, $18 \mathrm{~h}$;

(v) $\mathrm{MeOH}, \mathrm{Pd}(\mathrm{OH})_{2} / \mathrm{C}, \mathrm{H}_{2}$, r.t., $20 \mathrm{~h}$ then $60^{\circ} \mathrm{C}, 6 \mathrm{~h}$; (vi) $\mathrm{Ag}_{2} \mathrm{O}$, DCM, r.t., $16 \mathrm{~h}$;

(vii) $[\operatorname{lr}(\mathrm{COD}) \mathrm{Cl}]_{2}$, THF, DCM, r.t., $4 \mathrm{~h}$

Scheme 1 Synthetic route to 1 .

afforded the product, the phenoxide iridium carbene complex, $\mathbf{1}$. Key compounds have been characterised by NMR and MS as illustrated in the ESI. $\dagger$

In solution, complex $\mathbf{1}$ appears yellow/orange in colour. UV-Vis analysis in DCM showed it exhibits three absorption bands in the visible region of the spectrum (373, 425 and $490 \mathrm{~nm}$ ) with absorption coefficients in the range of charge transfer transitions (1017, 1326 and $\left.249 \mathrm{dm}^{3} \mathrm{~mol}^{-1} \mathrm{~cm}^{-1}\right)$. Work by Perutz et $a .^{23-26}$ has assigned similar bands in related square planar metal complexes to metal $\mathrm{d}-\mathrm{p}$ transitions although earlier assignments suggested they were metal-to-ligand charge transfer bands. ${ }^{27-29}$

At room temperature, the ${ }^{1} \mathrm{H}$ NMR spectrum of complex 1 in $\mathrm{CD}_{2} \mathrm{Cl}_{2}$ yields well resolved resonances (see Fig. 1). Two doublets at $\delta 6.53$ and 5.17 are observed for the $\mathrm{CH}_{2}$ linker protons which have a common ${ }^{2} J(\mathrm{HH})$ coupling of $14.9 \mathrm{~Hz}$. These two protons are diastereotopic due to the seven-membered metallocycle which is indicative of the retention of the Ir-O bond. ${ }^{30}$ Complex $\mathbf{1}$ is air/moisture sensitive but stable as a solid and in solution

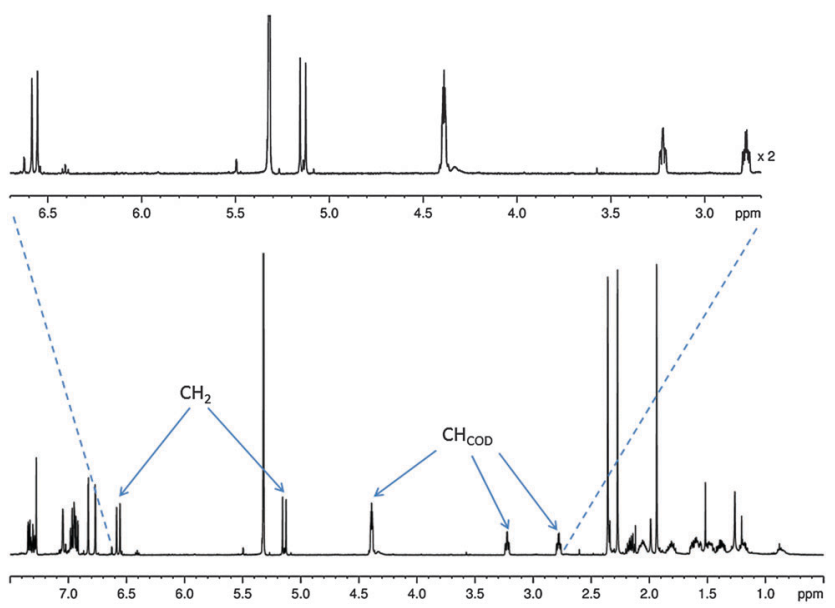

Fig. $1{ }^{1} \mathrm{H}$ NMR spectrum of 1 showing evidence for the diastereotopic $\mathrm{CH}_{2}$ linker protons with key $\mathrm{CH}$ resonances labelled. under $\mathrm{N}_{2}$. It also forms stable complexes once fully reacted with substrate and hydrogen as detailed in the following reactions.

Upon cooling a $\mathrm{CD}_{2} \mathrm{Cl}_{2}$ solution of complex 1 to $243 \mathrm{~K}$ all of its NMR signals become broad and undefined due to fluxional behaviour and when pyridine is added to this solution no reaction is evident. If, however, $\mathrm{H}_{2}$ gas is added at $255 \mathrm{~K}$, a limited reaction occurs as two pairs of hydride signals are now seen at $\delta-12.35$ and -18.25 (1.7\% conversion) and at $\delta-12.39$ and $-17.64(0.6 \%)$. These minor hydride containing products are conformational isomers of compound 2 (see Scheme 3) which arise due to differing metallocycle orientations; ${ }^{30}$ analogous behaviour has been reported. ${ }^{17}$

When $p-\mathrm{H}_{2}$ is used in this reaction, these hydride ligand signals do not show any significant ${ }^{1} \mathrm{H}$ NMR signal enhancement. However, the free $\mathrm{H}_{2}$ signal in these spectra is substantial which suggests that 1 undergoes rapid and reversible oxidative addition of $\mathrm{H}_{2}$ to form 2 which consumes the $p-\mathrm{H}_{2}$. There is no indication of the hydrogenation of COD at $255 \mathrm{~K}$ and upon warming to $298 \mathrm{~K}$, these hydride signals broaden into the baseline of the corresponding NMR spectra and strong signals for $\mathbf{1}$ are always visible.

When a $\mathrm{CD}_{2} \mathrm{Cl}_{2}$ solution of 1 reacts with both pyridine and $\mathrm{H}_{2}$ at $298 \mathrm{~K}$ a new neutral iridium species, $\operatorname{Ir}(\mathrm{H})_{2}\left(\kappa \mathrm{C}, \mathrm{O}-\mathrm{L}_{1}\right)(\mathrm{py})_{2}$, 3 is observed to slowly form containing two bound pyridine environments in a ratio of $1: 1$ (see ESI $\dagger$ for details). This species is also formed in $\mathrm{C}_{6} \mathrm{D}_{6}$. The mutually coupled inequivalent hydride signals appear in $\mathrm{CD}_{2} \mathrm{Cl}_{2}$ at $\delta-22.55$ and -25.49 $\left({ }^{2} J(\mathrm{HH})=8.1 \mathrm{~Hz}\right)$ and in $\mathrm{C}_{6} \mathrm{D}_{6}$ at $\delta-21.94$ and $-24.52\left({ }^{2} J(\mathrm{HH})=\right.$ $7.7 \mathrm{~Hz}$ ). Their inequivalence suggests $\mathrm{Ir}-\mathrm{O}$ bond retention, a fact which is further supported by the diastereotopic nature of the $\mathrm{CH}_{2}$ linker protons which appear as doublets in both $\mathrm{CD}_{2} \mathrm{Cl}_{2}$ and $\mathrm{C}_{6} \mathrm{D}_{6}$. Both complexes undergo pyridine and $\mathrm{H}_{2}$ exchange as highlighted in Scheme 2, although only the pyridine ligand trans to hydride dissociates. The use of EXSY NMR experiments enabled determination of experimental rate constants for pyridine loss in 3 at $294 \mathrm{~K}$ of $3.74 \pm 0.06 \mathrm{~s}^{-1}$ in $\mathrm{CD}_{2} \mathrm{Cl}_{2}$ and $13.5 \pm 0.6 \mathrm{~s}^{-1}$ in $\mathrm{C}_{6} \mathrm{D}_{6}$. The corresponding $\mathrm{H}_{2}$ loss rates were $0.80 \pm 0.01 \mathrm{~s}^{-1}$ and $3.02 \pm 0.07 \mathrm{~s}^{-1}$ respectively and are therefore much slower than those of pyridine loss.

This behaviour changes significantly upon moving to protic methanol. Now, the addition of $\mathrm{H}_{2}$ to a $\mathrm{CD}_{3} \mathrm{OD}$ solution of complex 1 at $250 \mathrm{~K}$, results in a very limited reaction to form a dihydride $(<1 \%$, with resonances at $\delta-12.65$ and -18.27 and the low concentration presumably prevents observation of its conformational isomer) but upon warming further, rapid and total decomposition of $\mathbf{1}$ follows. In contrast, the addition of pyridine to a $\mathrm{CD}_{3} \mathrm{OD}$ solution of complex 1 at $243 \mathrm{~K}$ forms the

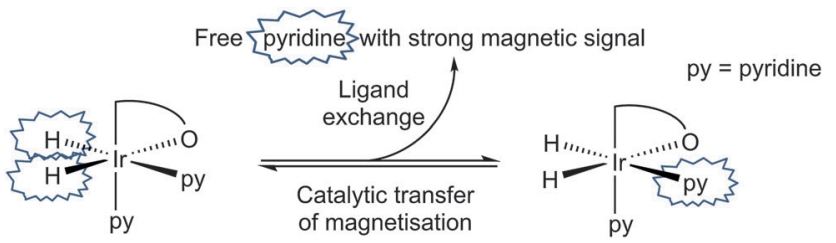

Scheme 2 Transfer of hydride polarisation into the indicated pyridine ligand is followed by ligand exchange to build-up hyperpolarised pyridine in solution. 


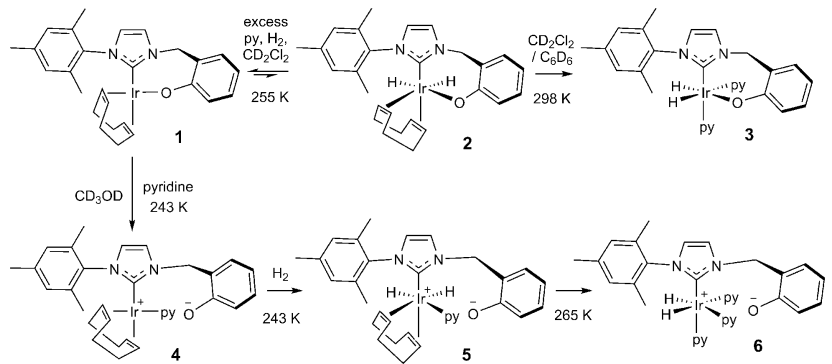

Scheme 3 Species formed during the reaction of 1 with $\mathrm{H}_{2}$ and pyridine in $\mathrm{CD}_{3} \mathrm{OD}(\mathbf{4}, \mathbf{5}$ and $\mathbf{6})$ and $\mathrm{CD}_{2} \mathrm{Cl}_{2}(\mathbf{2}$ and $\mathbf{3})$ or $\mathrm{C}_{6} \mathrm{D}_{6}$ (3) solution.

phenolate dissociation product, square planar 4 quantitatively (see Scheme 3 and ESI $\dagger$ ) where the COD ligand yields four inequivalent alkene proton resonances.

Upon the addition of $p-\mathrm{H}_{2}$ and pyridine to 4 at $243 \mathrm{~K}$, two PHIP enhanced hydride signals become immediately visible at $\delta-12.34$ and -17.50 that are shown to couple via COSY. They arise from $\mathrm{H}_{2}$ addition to 4 which initially forms the alkene dihydride complex, 5. The $\mathrm{CH}_{2}$ linker protons of $\mathbf{5}$ remain diastereotopic on phenolate rotation due to the absence of a mirror plane. Upon warming to $265 \mathrm{~K}$, this system evolves further and a single hydride signal becomes visible at $\delta-22.18$ due to the formation of $\left[\operatorname{Ir}(\mathrm{H})_{2}\left(\kappa \mathrm{C}, \mathrm{O}^{-}-\mathrm{L}_{1}\right)(\mathrm{py})_{3}\right]^{+}, \mathbf{6}$; the COD is converted to cyclooctene. Further NMR analysis confirms that 6 contains two bound pyridine ligand environments, in a $2: 1$ ratio, two hydride ligands and an iridium-carbene bond. Its $\mathrm{CH}_{2}$ linker protons are now equivalent, appearing as a singlet at $\delta 4.83$ due to the existence of a mirror plane as detailed in Scheme 3.

Complex 6 is zwitterionic, and its cationic $\operatorname{Ir}(\mathrm{III})$ centre is balanced by phenoxide ion formation. Hence the final reaction product formed from $\mathbf{1}$ with pyridine and $\mathrm{H}_{2}$ is solvent dependent. The two pyridine ligands of $\mathbf{6}$ that lie trans to hydride are shown to dissociate with an experimental rate constant of $1.35 \pm 0.03 \mathrm{~s}^{-1}$ at $294 \mathrm{~K}$, although no exchange of the pyridine trans to the carbene is observed. In $\mathrm{CD}_{3} \mathrm{OD}$, rapid $\mathrm{H} / \mathrm{D}$ exchange, accompanied by $\mathrm{HD}$ formation, is observed which prevents the quantification of the $\mathrm{H}_{2}$ loss rate in this solvent. At $294 \mathrm{~K}$, the ligand exchange rates of species 3 in $\mathrm{C}_{6} \mathrm{D}_{6}$ are therefore much faster than those in $\mathrm{CD}_{2} \mathrm{Cl}_{2}$, but both are faster than those of 6 in $\mathrm{CD}_{3} \mathrm{OD}$ as shown in the ESI. +

The ligand exchange rates of 6 in $\mathrm{CD}_{3} \mathrm{OH}$ were examined as a function of temperature and activation parameters for these processes were calculated (see ESI $\dagger$ ). The activation enthalpy values for both pyridine and hydride loss are very similar to each other $\left(90.7 \pm 1.6 \mathrm{~kJ} \mathrm{~mol}^{-1}\right.$ and $88.3 \pm 9.1 \mathrm{~kJ} \mathrm{~mol}^{-1}$ respectively). The entropy of activation values of $71.3 \pm$ $5.3 \mathrm{~J} \mathrm{~K}^{-1}$ and $56.1 \pm 30.6 \mathrm{~J} \mathrm{~K}^{-1}$ for pyridine and hydride loss respectively are also similar and positive thereby confirming the dissociative character of these steps. ${ }^{7}$ Similar ligand exchange processes, in a series of related complexes, yield values of similar size. $^{7,32}$ A ligand exchange mechanism featuring reversible pyridine dissociation with $\mathrm{H}_{2}$ loss via $\left[\operatorname{Ir}\left(\kappa \mathrm{C}, \mathrm{O}^{-}-\mathrm{L}_{1}\right)(\mathrm{H})_{2}\left(\mathrm{H}_{2}\right)(\mathrm{py})_{2}\right]^{+}$ is therefore indicated. ${ }^{33}$

Both catalysts 3 and 6 therefore exhibit the substrate and $\mathrm{H}_{2}$ exchange characteristics required for them to act as SABRE

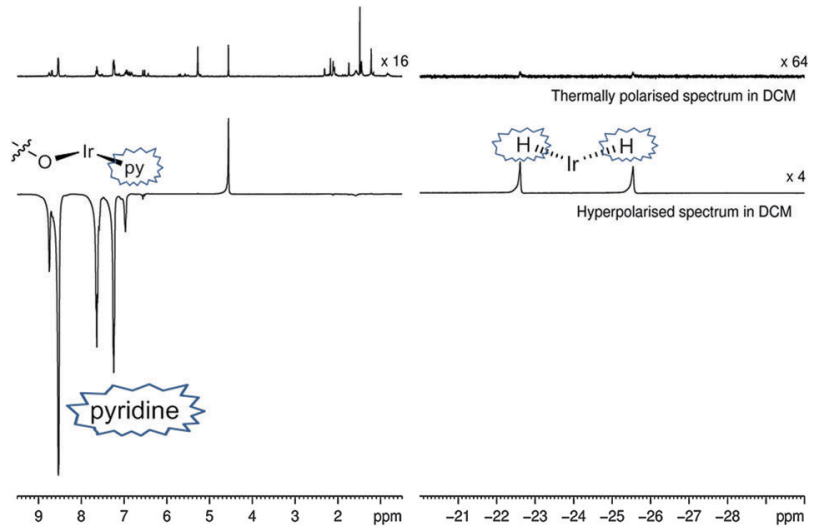

Fig. 2 Thermally polarised and hyperpolarised ${ }^{1} \mathrm{H}$ NMR spectra of a $\mathrm{CD}_{2} \mathrm{Cl}_{2}$ solution containing $0.06 \mathrm{M}$ pyridine, $11 \mathrm{~mol} \% 1$ and 3 bars $p-\mathrm{H}_{2}$. The enhanced signals for free and bound pyridine (in 3 ) and the corresponding hydride ligands are indicated.

catalysts. To test their substrate signal enhancing performance, samples were prepared containing catalyst $\mathbf{1}$ and a chosen substrate in the desired NMR solvent. These were rigorously degassed before the addition of 3 bars of $\mathrm{H}_{2}$. Samples were tested by reintroducing $p-\mathrm{H}_{2}$ into the headspace of the NMR tube, shaking the sample in the low field outside of the spectrometer and then rapidly transferring the sample into the spectrometer for examination. This resulted in the observation of enhanced signals in the corresponding single scan ${ }^{1} \mathrm{H}$ NMR spectra for the hydride ligands, bound substrate and free substrate in solution as exemplified by Fig. 2. The total enhancement value seen for the five protons of pyridine in $\mathrm{C}_{6} \mathrm{D}_{6}$ proved to be 1850 -fold under the conditions detailed. For $\mathrm{CD}_{2} \mathrm{Cl}_{2}$ this enhancement level was reduced to $c a$. 1660-fold whilst for $\mathrm{CD}_{3} \mathrm{OD}$ solution it became 710 -fold. Given the corresponding gain in signal-to-noise levels that these enhancements

Table 1 Maximum ${ }^{1} \mathrm{H}$ NMR SABRE enhancements (fold) observed for solutions containing pyridine $(0.06 \mathrm{M}$ and $11 \mathrm{~mol} \% \mathrm{1})$, nicotinaldehyde (0.05 $\mathrm{M}$ and $14 \mathrm{~mol} \% \mathrm{1}$ ) and nicotine $(0.04 \mathrm{M}$ and $16 \mathrm{~mol} \% \mathrm{1})$ in $\mathrm{CD}_{2} \mathrm{Cl}_{2}$, $\mathrm{C}_{6} \mathrm{D}_{6}$ and $\mathrm{CD}_{3} \mathrm{OD}$ under 3 bars $p-\mathrm{H}_{2}$

\begin{tabular}{llcl}
\hline & \multicolumn{3}{l}{ Pyridine ${ }^{1} \mathrm{H}$ NMR SABRE enhancement (fold) } \\
\cline { 2 - 4 } Solvent & ortho & meta & para \\
\hline $\mathrm{C}_{6} \mathrm{D}_{6}$ & $843 \pm 27$ & $600 \pm 30$ & $404 \pm 13$ \\
$\mathrm{CD}_{2} \mathrm{Cl}_{2}$ & $877 \pm 32$ & $337 \pm 57$ & $450 \pm 22$ \\
$\mathrm{CD}_{3} \mathrm{OD}$ & $426 \pm 5$ & $47 \pm 28$ & $243 \pm 3$ \\
\hline
\end{tabular}

Nicotinaldehyde ${ }^{1} \mathrm{H}$ NMR SABRE enhancement (fold)

\begin{tabular}{llccc} 
Solvent & $\mathrm{H}_{\mathrm{A}}$ & $\mathrm{H}_{\mathrm{B}}$ & $\mathrm{H}_{\mathrm{C}}$ & $\mathrm{H}_{\mathrm{D}}$ \\
\hline $\mathrm{C}_{6} \mathrm{D}_{6}$ & $259 \pm 17$ & $209 \pm 22$ & $118 \pm 22$ & $244 \pm 18$ \\
$\mathrm{CD}_{2} \mathrm{Cl}_{2}$ & $486 \pm 36$ & $400 \pm 32$ & $148 \pm 34$ & $396 \pm 65$ \\
$\mathrm{CD}_{3} \mathrm{OD}$ & $62 \pm 7$ & $59 \pm 10$ & $26 \pm 7$ & $65 \pm 6$ \\
\hline
\end{tabular}

Nicotine ${ }^{1} \mathrm{H}$ NMR SABRE enhancement (fold)

\begin{tabular}{lcccc}
\cline { 2 - 5 } Solvent & $\mathrm{H}_{\mathrm{A}}$ & \multicolumn{1}{c}{$\mathrm{H}_{\mathrm{B}}$} & \multicolumn{1}{c}{$\mathrm{H}_{\mathrm{C}}$} & \multicolumn{1}{c}{$\mathrm{H}_{\mathrm{D}}$} \\
\hline $\mathrm{C}_{6} \mathrm{D}_{6}$ & $400 \pm 54$ & $315 \pm 48$ & $88 \pm 30$ & $338 \pm 80$ \\
$\mathrm{CD}_{2} \mathrm{Cl}_{2}$ & $419 \pm 51$ & $381 \pm 48$ & $146 \pm 44$ & $386 \pm 55$ \\
$\mathrm{CD}_{3} \mathrm{OD}$ & $29 \pm 4$ & $28 \pm 3$ & $3 \pm 3$ & $31 \pm 3$
\end{tabular}


provide, the resulting time savings are substantial in all solvents. For comparison purposes, the site specific enhancement values for the substrates pyridine, nicotinaldehyde and nicotine are summarised in Table 1 . The performance of $\mathbf{1}$ as a SABRE catalyst for pyridine like substrates has therefore been established.

It is known that the amount of signal enhancement observed in the ${ }^{1} \mathrm{H}$ NMR spectrum of a substrate under SABRE is significantly affected by the ligand exchange rates, as previously explained by Green et al. ${ }^{34}$ For comparison, $\left[\operatorname{Ir}(\mathrm{H})_{2}(\mathrm{IMes})(\mathrm{py})_{3}\right] \mathrm{Cl}$, is commonly used as the catalyst benchmark for SABRE and its pyridine dissociation rate ${ }^{32}$ was found to be $23 \mathrm{~s}^{-1}$. While the ligand dissociation rates for $\mathbf{3}$ and $\mathbf{6}$ are much lower, they still achieve good hyperpolarisation levels. In fact, these data show that one pyridine substrate trans to hydride in $\mathrm{CD}_{2} \mathrm{Cl}_{2}$ or $\mathrm{C}_{6} \mathrm{D}_{6}$ is more efficient at receiving SABRE than the two equivalent pyridine ligands of 6 in $\mathrm{CD}_{3} \mathrm{OD}$. Furthermore, the concept of an active solvent responsive catalyst is illustrated.

In summary, the iridium precatalyst $\operatorname{Ir}\left(\kappa \mathrm{C}, \mathrm{O}-\mathrm{L}_{1}\right)(\mathrm{COD}), \mathbf{1}$ containing a phenolate substituted NHC has been synthesised and shown to act as an efficient SABRE catalyst precursor. The active catalytic species is solvent dependent. Complex $\mathbf{1}$ contains an Ir-O bond which is affected by solvent polarity and proton availability; in non-polar $\mathrm{C}_{6} \mathrm{D}_{6}$ and polar aprotic $\mathrm{CD}_{2} \mathrm{Cl}_{2}$, this bond is strong and substitution resistant with 1 forming $\operatorname{Ir}\left(\kappa \mathrm{C}, \mathrm{O}-\mathrm{L}_{1}\right)(\mathrm{H})_{2}(\mathrm{py})_{2}(3)$ on reaction with $\mathrm{H}_{2}$ and pyridine. In contrast, on changing to polar protic methanol, the $\mathrm{Ir}-\mathrm{O}$ bond becomes labile and the phenolate easily dissociates from the iridium centre, such that zwitterionic $\left[\operatorname{Ir}\left(\kappa \mathrm{C}, \mathrm{O}^{-}-\mathrm{L}_{1}\right)(\mathrm{H})_{2}(\mathrm{py})_{3}\right]^{+}$(6) forms. 6 is directly analogous to the efficient SABRE catalyst $\left[\operatorname{Ir}(\mathrm{H})_{2}(\mathrm{IMes})(\mathrm{py})_{3}\right] \mathrm{Cl}$ which performs well in $\mathrm{CD}_{3} \mathrm{OD}$ but has lower activity in non-polar $\mathrm{CD}_{2} \mathrm{Cl}_{2}$ and $\mathrm{C}_{6} \mathrm{D}_{6}$. Both 3 and 6 undergo pyridine and $\mathrm{H}_{2}$ exchange thereby enabling them to act as SABRE catalysts. Whilst 6 works well in $\mathrm{CD}_{3} \mathrm{OD}$, catalyst neutrality in the non-polar solvents $\mathrm{CD}_{2} \mathrm{Cl}_{2}$ and $\mathrm{C}_{6} \mathrm{D}_{6}$ results in the formation of 3 which is highly active for SABRE catalysis. This study therefore shows that catalyst design and control can lead to improved magnetisation transfer in a range of solvents, a requirement for future studies that seek to identify low concentration analytes ${ }^{35-37}$ and to produce hyperpolarised MRI contrast agents.

We acknowledge Bruker Biospin and the EPSRC for a studentship (1359398) and the Wellcome Trust and Wolfson Foundation (092506 and 098335) for their generous funding. We thank Dr Jason Lynam, Prof. Gary Green and Dr Ryan Mewis for helpful comments.

\section{References}

1 T. C. Eisenschmid, R. U. Kirss, P. P. Deutsch, S. I. Hommeltoft, R. Eisenberg, J. Bargon, R. G. Lawler and A. L. Balch, J. Am. Chem. Soc., 1987, 109, 8089.

2 C. R. Bowers and D. P. Weitekamp, J. Am. Chem. Soc., 1987, 109, 5541.

3 R. W. Adams, S. B. Duckett, R. A. Green, D. C. Williamson and G. G. R. Green, J. Chem. Phys., 2009, 131, 194505.

4 K. D. Atkinson, M. J. Cowley, S. B. Duckett, P. I. P. Elliott, G. G. R. Green, J. Lopez-Serrano, I. G. Khazal and A. C. Whitwood, Inorg. Chem., 2009, 48, 663.

5 K. D. Atkinson, M. J. Cowley, P. I. P. Elliott, S. B. Duckett, G. G. R. Green, J. Lopez-Serrano and A. C. Whitwood, J. Am. Chem. Soc., 2009, 131, 13362.
6 B. J. A. van Weerdenburg, S. Gloggler, N. Eshuis, A. H. J. Engwerda, J. M. M. Smits, R. de Gelder, S. Appelt, S. S. Wymenga, M. Tessari, M. C. Feiters, B. Blumich and F. P. J. T. Rutjes, Chem. Commun., 2013, 49, 7388.

7 M. J. Cowley, R. W. Adams, K. D. Atkinson, M. C. R. Cockett, S. B. Duckett, G. G. R. Green, J. A. B. Lohman, R. Kerssebaum, D. Kilgour and R. E. Mewis, J. Am. Chem. Soc., 2011, 133, 6134.

8 J.-B. Hoevener, N. Schwaderlapp, R. Borowiak, T. Lickert, S. B. Duckett, R. E. Mewis, R. W. Adams, M. J. Burns, L. A. R. Highton, G. G. R. Green, A. Olaru, J. Hennig and D. von Elverfeldtt, Anal. Chem., 2014, 86, 1767.

9 R. E. Mewis, K. D. Atkinson, M. J. Cowley, S. B. Duckett, G. G. R. Green, R. A. Green, L. A. R. Highton, D. Kilgour, L. S. Lloyd, J. A. B. Lohman and D. C. Williamson, Magn. Reson. Chem., 2014, 52, 358.

10 M. L. Truong, F. Shi, P. He, B. Yuan, K. N. Plunkett, A. M. Coffey, R. V. Shchepin, D. A. Barskiy, K. V. Kovtunov, I. V. Koptyug, K. W. Waddell, B. M. Goodson and E. Y. Chekmenev, J. Phys. Chem. B, 2014, 118, 13882.

11 H. Zeng, J. Xu, J. Gillen, M. T. McMahon, D. Artemov, J.-M. Tyburn, J. A. B. Lohman, R. E. Mewis, K. D. Atkinson, G. G. R. Green, S. B. Duckett and P. C. M. van Zijl, J. Magn. Reson., 2013, 237, 73.

12 E. B. Dücker, L. T. Kuhn, K. Münnemann and C. Griesinger, J. Magn. Reson., 2012, 214, 159.

13 A. N. Pravdivtsev, A. V. Yurkovskaya, H. Zimmermann, H.-M. Vieth and K. L. Ivanov, RSC Adv., 2015, 5, 63615.

14 L. T. Kuhn, U. Bommerich and J. Bargon, J. Phys. Chem. A, 2006, 110, 3521.

15 V. V. Zhivonitko, I. V. Skovpin and I. V. Koptyug, Chem. Commun., 2015, 51, 2506.

16 M. Fekete, O. Bayfield, S. B. Duckett, S. Hart, R. E. Mewis, N. Pridmore, P. J. Rayner and A. Whitwood, Inorg. Chem., 2013, 52, 13453.

17 A. J. Ruddlesden, R. E. Mewis, G. G. R. Green, A. C. Whitwood and S. B. Duckett, Organometallics, 2015, 34, 2997.

18 V. L. Schuster, Y. Chi, A. S. Wasmuth and R. S. Pottorf, G. L. Olson and W. I. P. Organisation, WO2011/37610 A1, Albert Einstein College Of Medicine Of Yeshiva University, US, 2011.

19 G. Sagrera and G. Seoane, Synthesis, 2009, 4190.

20 R. V. Somu, H. Boshoff, C. Qiao, E. M. Bennett, C. E. Barry and C. C. Aldrich, J. Med. Chem., 2005, 49, 31.

21 G. Occhipinti, V. R. Jensen, K. W. Tornroos, N. A. Froystein and H. R. Bjorsvik, Tetrahedron, 2009, 65, 7186.

22 J. L. Herde, J. C. Lambert and C. V. Senoff and M. A. Cushing, Inorg. Syn., John Wiley \& Sons, Inc., 2007.

23 M. V. Campian, R. N. Perutz, B. Procacci, R. J. Thatcher, O. Torres and A. C. Whitwood, J. Am. Chem. Soc., 2012, 134, 3480.

24 M. C. Nicasio, R. N. Perutz and A. Tekkaya, Organometallics, 1998, 17, 5557.

25 L. Cronin, M. C. Nicasio, R. N. Perutz, R. G. Peters, D. M. Roddick and M. K. Whittlesey, J. Am. Chem. Soc., 1995, 117, 10047.

26 C. Hall, W. D. Jones, R. J. Mawby, R. Osman, R. N. Perutz and M. K. Whittlesey, J. Am. Chem. Soc., 1992, 114, 7425.

27 G. L. Geoffroy, H. Isci, J. Litrenti and W. R. Mason, Inorg. Chem., 1977, 16, 1950.

28 R. Brady, B. R. Flynn, G. L. Geoffroy, H. B. Gray, J. Peone and L. Vaska, Inorg. Chem., 1976, 15, 1485.

29 G. L. Geoffroy, G. S. Hammond and H. B. Gray, J. Am. Chem. Soc., 1975, 97, 3933.

30 H. M. Peng, R. D. Webster and X. Li, Organometallics, 2008, 27, 4484.

31 K. Stott, J. Keeler, Q. N. Van and A. J. Shaka, J. Magn. Reson., 1997, 125, 302.

32 L. S. Lloyd, A. Asghar, M. J. Burns, A. Charlton, S. Coombes, M. J. Cowley, G. J. Dear, S. B. Duckett, G. R. Genov, G. G. R. Green, L. A. R. Highton, A. J. J. Hooper, M. Khan, I. G. Khazal, R. J. Lewis, R. E. Mewis, A. D. Roberts and A. J. Ruddlesden, Catal. Sci. Technol., 2014, 4, 3544.

33 D. A. Barskiy, A. N. Pravdivtsev, K. L. Ivanov, K. V. Kovtunov and I. V. Koptyug, Phys. Chem. Chem. Phys., 2016, 18, 89.

34 R. A. Green, R. W. Adams, S. B. Duckett, R. E. Mewis, D. C. Williamson and G. G. R. Green, Prog. Nucl. Magn. Reson. Spectrosc., 2012, 67, 1.

35 N. Eshuis, N. Hermkens, B. J. A. van Weerdenburg, M. C. Feiters, F. P. J. T. Rutjes, S. S. Wijmenga and M. Tessari, J. Am. Chem. Soc., 2014, 136, 2695.

36 N. Eshuis, R. L. E. G. Aspers, B. J. A. van Weerdenburg, M. C. Feiters, F. P. J. T. Rutjes, S. S. Wijmenga and M. Tessari, Angew. Chem., Int. Ed., 2015, 54, 14527.

37 N. Eshuis, B. J. A. van Weerdenburg, M. C. Feiters, F. P. J. T. Rutjes, S. S. Wijmenga and M. Tessari, Angew. Chem., Int. Ed., 2015, $\mathbf{5 4}, 1481$. 